\title{
Modeling the dispersion of endocrine disruptors in the Santos Estuarine System (Sao Paulo State, Brazil)
}

\author{
Giovana Teixeira Gimiliani $^{1 *}$, Roberto Fioravanti Carelli Fontes ${ }^{l}$, Denis Moledo de Souza Abessa ${ }^{l}$
}

\author{
${ }^{1}$ Universidade Estadual Paulista "Júlio de Mesquita Filho" - Campus do Litoral Paulista. \\ (Praça Infante Dom Henrique, s/n, 1330-900, São Vicente, SP, Brasil) \\ *Corresponding author: gtgimiliani@hotmail.com
}

\section{ABstract}

Estrogens are hormones responsible for growth and reproduction. They are naturally synthesized by animals and humans alike. Xenoestrogens are identical to natural hormones, but they are manmade and used as oral contraceptives. Xenoestrogens are a specific group of drugs found in domestic wastewater and some environmental matrices. These compounds remain after conventional sewage treatment and, consequently, affect both the environment and non-target aquatic organisms. In this study, we used the Delft3D hydrodynamic model to estimate the amount of both natural and synthetic estrogens that have been released in the Estuarine System of Santos and São Vicente and the Santos Bay. The data on flow from the sewage treatment plants and on average concentrations of natural and synthetic estrogens released in aquatic environments were obtained from the literature. The results of the modeling showed higher concentrations of estrogens in the estuarine waters of the Largo Pompeba region, the São Vicente Canal, and the Santos Bay, which are regions that receive greater inflows of domestic sewage. The results also suggest that higher concentrations of estrogenic compounds are expected to be found in areas with higher levels of salinity.

Descriptors: Estrogens, Dispersion, Delft 3, Santos Estuarine System, Santos Bay.

\section{RESUMo}

Estrogênios são hormônios responsáveis pelo crescimento e reprodução, sendo naturalmente sintetizados por animais e seres humanos. Os xenoestrogênios são hormônios idênticos aos naturais, porém fabricados pelo homem e utilizados como contraceptivos orais. Xenoestrogênios formam um grupo específico de fármacos encontrados em efluentes domésticos e em algumas matrizes ambientais. Estes compostos persistem nos tratamentos convencionais de esgotos e, consequentemente, atingem os ambientes e os organismos aquáticos não alvos. Neste trabalho, foi estimada a dispersão de estrogênios naturais e sintéticos quando estes são possivelmente lançados no Sistema Estuarino de Santos e São Vicente e Baía de Santos, utilizando o modelo hidrodinâmico Delft3D. Os dados das vazões de estações de tratamento de esgotos e de concentrações médias de estrogênios naturais e sintéticos lançadas nos ambientes aquáticos foram obtidos da literatura. Os resultados mostraram concentrações mais elevadas de estrogênios nas águas estuarinas da região do Largo da Pompeba, Canal de São Vicente, e na Baía de Santos, sendo estas as regiões que recebem maior aporte de esgotos domésticos. Os resultados da modelagem sugerem ainda que maiores concentrações dos compostos estrogênicos são esperadas nos locais com níveis mais elevados de salinidade.

Descritores: Estrogênios, Dispersão, Delft 3D, Sistema Estuarino de Santos, Baía de Santos. 


\section{INTRODUCTION}

Estrogenic hormones are primarily responsible for the growth and maintenance of a healthy reproductive system of both humans and animals. Estrogens in the form of estradiol and estrone are naturally secreted by women in amounts of approximately 2-12 mg and 3-20 mg per individual per day, respectively (YING et al., 2002; JOBLING et al., 1998).

Ethinylestradiol (EE2), or xenoestrogen, is a synthetic estrogen used as an oral contraceptive and an additive in animal feed (GHISELLI; JARDIM, 2007).

Natural and synthetic estrogens are a group of the most potent class of drugs found worldwide in different environmental matrices. Estrogens and their metabolites have been identified in domestic sewage in nature, in effluents from wastewater treatment plants (WWTPs), and in surface and drinking waters (BILA; DEZOTTI, 2007; MULROY, 2001; TERNES, 2001; BELFROID et al., 1999; STUMPF et al., 1999; TERNES et al., 1999).

Effluents from both WWTPs and preconditioning stations combined with ocean disposal systems (outfalls) represent the main sources of estrogenic compounds in the aquatic environment, since such processes do not allow for the complete removal of these compounds (TERNES et al., 1999).

The amounts of estrogen identified in effluents are enough to induce vitellogenin synthesis (VTG), changes in gonads, impaired reproduction, and increased offspring mortality in aquatic organisms (PAWLOWSKI et al., 2004; FOLMAR et al., 2000; RODGRES-GRAY et al., 2000; ROUTLEDGE et al., 1998).

Few studies have documented the presence of estrogens in marine and estuarine environments (ROBINSON et al., 2009; ISOBE et al., 2006), and data on the persistence of these compounds in environmental compartments is scarce.

For a better understanding of the dispersion and transport of estrogenic compounds throughout coastal regions, the use of hydrodynamic models is a useful option for making environmental predictions in environmental monitoring studies. The current study estimated the dispersion of natural and synthetic estrogens in the Santos Estuarine System using the Delft-3D hydrodynamic model combined with a water quality module.

\section{MATERIAL AND METHODS}

\section{STUDY AREA}

The Santos Estuarine System (SES) is located on the central coast of the state of São Paulo, Brazil $\left(23^{\circ} 30^{\prime} 5^{\prime \prime} \mathrm{S}-24^{\circ} \mathrm{S} ; 46^{\circ} 05^{\prime} \mathrm{W}-46^{\circ} 30^{\prime} \mathrm{W}\right)$. It is within the Santos Metropolitan Region, which is the third largest metropolitan region in São Paulo State, with an area of $2.373 \mathrm{~km}^{2}$ and 1.7 million inhabitants. The SES is part of the Santos Metropolitan Region and covers approximately $300 \mathrm{~km}^{2}$. It is home to almost 1 million residents. Figure 1 shows the domain studied, as well as its bathymetry and point-sources of sewage discharge.

Only part of the local population lives in areas with sewage collection and have their effluents treated before disposal into the estuary. The discharge of treated and untreated sewage into the water bodies of the region has caused the contamination of the waters, sediments, and biota. Thus, sewage is considered one of the major problems of the SES.

The SES is a complex of continental water pathways connected to the Santos Bay, mostly through the Santos Canal (port access) and the São Vicente Channel, a longer and shallower connection. Other channels, rivers, creeks, and urban drainage canals help to form the estuarine complex. The SES includes a set of important ecosystems which, due to their fragility and lack of resilience, have their flora and fauna threatened by human activity.

The largest Brazilian industrial complex is located in this densely urbanized region and consists of major petrochemical, steel, and fertilizer factories. The largest port complex in Latin America (the Port of Santos) is located within the SES.

Apart from its noteworthy economic importance to the country, the region is also of considerable environmental relevance, since the SES is surrounded by mangrove swamps. These swamps account for $43 \%$ of the total mangrove area of the state of São Paulo (LAMPARELLI et al., 2001). Tourism, fishery and recreational activities are also popular in the region. In addition to the natural variation in the water intakes that flow into the estuary, there is a well-established urban drainage system (local and remote) that flows to the coast, as well as a hydropower plant which is connected to a national electricity system network.

These interferences significantly increase the fresh water flow into the estuary. Their impacts are not yet completely known nor measurable.

HARARI et al. (2008) measured the physical properties of the SES and found salinity to be more important than temperature in terms of density and buoyancy in the estuary. Water temperature ranged from 
19 to $24^{\circ} \mathrm{C}$, depending on the season. Salinity, which is also influenced by the season, varied from 15 to 35 . Tides act as stirring mechanisms, and the result is an estuary that is partially mixed in its middle portion most of the time, and slightly mixed at its heads. The tidal regime is semidiurnal, with some degree of diurnal inequality ( $F$ $=0.30$ ) and an amplitude ranging from 0.14 to $0.60 \mathrm{~m}$, accordingly to the neap and spring periods.

HARARI et al. (2008) found that neap tidal currents in the major channel oscillate between -0.22 and $0.26 \mathrm{~ms}^{-1}$ at $5 \mathrm{~m}$ depth and between -0.15 and $0.25 \mathrm{~ms}^{-1}$ at $10 \mathrm{~m}$ depth $(+$ mean outflow, down the estuary). Currents are more energetic during the spring tidal cycles, varying from -0.35 to 0.30 at $5 \mathrm{~m}$ depth and from -0.26 to 0.25 at $10 \mathrm{~m}$ depth.

River inflow contributions do not have any major influence on the estuarine dynamics: the highest flow perceived during summer is approximately $60 \mathrm{~m}^{-1}$, which is distributed throughout the whole system (FRF, 2008).

MIRANDA et al. (2012) measured the thermohaline properties and currents in the northernmost portion of the SES during the winter and found velocities varying from -0.20 to $0.30 \mathrm{~ms}^{-1}$ ( $\mathrm{v}>0$ corresponding to the ebb flow) during neap tidal cycles. Salinity stratification was relatively weak, with small variations from the surface to the bottom ( $\mathrm{S}=26.4$ to $\mathrm{S}=30.7$, respectively). During the spring tides, currents increased to - a range of 0.40 to $0.45 \mathrm{~ms}^{-11}$, while salinity stratification remained the same. The authors concluded that the driving mechanism in the estuarine circulation and mixing was the imbalance between fresh water discharge and the baroclinic component of the pressure gradient. They also concluded that fortnightly tidal modulation does not lead to any significant changes in circulation or salinity stratification.

\section{The Delft3D Model Suite}

The kernel module of the Delft3D Suite of models is the Delft3D-FLOW, which solves the three-dimensional Navier-Stokes equations for an incompressible fluid, under the non-hydrostatic and Boussinesq approximations for a non-inertial system of reference. A detailed formulation and discretization of momentum equations can be found in Deltares (2013). The Delft3D-FLOW module employs a horizontal, curvilinear and orthogonal mesh of finite differences, capable of best fitting the computational domain to the geographical coastline. Vertical discretization uses sigma coordinate transformation, which ensures that depth variations maintain proper resolution into both the superficial and bottom boundary layers. It is, in fact, a four-dimensional model, because it allows for the simulation to run in the time domain, which helps to best evaluate estuary dynamics in terms of tides, river intakes, mixing processes, and effects of buoyancy. The system of equations is completed from the diffusion of heat and salt, turbulence, continuity, and a state equation for density.

The Delft3D-WAQ is a three-dimensional module that defines water quality, which solves advection-diffusionreaction equations in a computational mesh. This model makes use of hydrodynamic conditions (salinity, density, water elevation, and velocity), which are calculated using the Delft3D-FLOW model.

\section{DATASET}

\section{FLOW DATA}

The flow data from the Santos drainage channels, sewage point, and diffuse sources used in this study were derived from the model that was implemented in the Laboratory of Estuarine Dynamics and Coastal Seas (LADIN / EMC) at São Paulo State University in São Vicente (UNESP). The flow of sewage effluents from both unregulated sources and WWTPs was obtained by SAMPAIO et al. (2008). The current flow of the outfall from Santos was obtained by LAMPARELLI and ORTIZ (2006). The river sources and natural inputs used herein were taken from a diagram compiled by SAMPAIO et al. (2008) (Table 1).

Table 1. Sewage discharge points and the respective effluent flows for the regions within the SES (Adapted from SAMPAIO et al., 2008).

\begin{tabular}{lc}
\hline Sewage discharge points & Flow $\left(\mathrm{m}^{3} \mathrm{~s}^{-1}\right)$ \\
\hline Not treated & 0.436 \\
Cubatão STP & 0.2 \\
Humaitá STP & 0.04 \\
Santos submarine outfall & 3.0 \\
Channel 1 & 3.82 \\
Channel 2 & 1.46 \\
Channel 3 & 1.79 \\
Channel 4 & 1.79 \\
Channel 5 & 1.18 \\
Channel 6 & 1.18 \\
\hline
\end{tabular}




\section{PhysicochemicAl PROPERTIES OF ESTROGENS}

The dispersal, transport, and biological effects of estrogen in surface waters all depend on a number of physical processes (dilution, advection and dispersion), chemical processes (sorption, volatilization, and photolysis), and biological processes (biodegradation, bio-activation) (WRITER et al., 2012).

For the sorption process, both estrogen distribution and estrogen partitioning in the environment are determined by physicochemical properties and sitespecific environmental conditions (YING et al., 2002). (Table 2).

Table 2. Physicochemical properties of estrogens (LAI et al., 2000).

\begin{tabular}{lccccc}
\hline Estrogen & $\begin{array}{c}\text { Molecular } \\
\text { weight } \\
\left(\mathrm{g} \mathrm{mol}^{-1}\right)\end{array}$ & $\begin{array}{c}\text { Water } \\
\text { solubility } \\
\left(\mathrm{mg} \mathrm{L}^{-1} \text { at }\right. \\
\left.20^{\circ} \mathrm{C}\right)\end{array}$ & $\begin{array}{c}\text { Vapor } \\
\text { pressure } \\
(\mathrm{mm} \\
\mathrm{Hg})\end{array}$ & $\begin{array}{c}\text { log } \\
\text { Kow }\end{array}$ & $\begin{array}{c}\text { log } \\
\text { Koc }\end{array}$ \\
\hline Estrone & 270.4 & 13 & $\begin{array}{c}2.3 \mathrm{x} \\
10-10\end{array}$ & 3.43 & 4.882 \\
Estradiol & 272.4 & 13 & $\begin{array}{c}2.3 \mathrm{x} \\
10-10\end{array}$ & 3.94 & 3.300 \\
& & & $4.5 \mathrm{x}$ & & \\
EE2 & 296.4 & 4.8 & $10-11$ & 4.15 & 4.770 \\
\hline
\end{tabular}

Estrogens are hydrophobic organic compounds of low volatility and are moderately adsorbed by sediment. The sorption of estrogens in soil or sediment may be an important factor in reducing aqueous phase concentrations. It may also be correlated with the presence of organic carbon content, and it may increase as salinity levels in the water increase (YING et al., 2002; LAI et al., 2000).

Information on the average concentrations of synthetic and natural estrogens was obtained from the paper by TERNES et al. (1999) on the domestic sewage from the STP in Rio de Janeiro, Brazil. These average concentrations, which were detected within Brazil and which resulted from Brazilian environmental and temperature conditions, were chosen because variations in estrogen concentrations are influenced by environmental, physical, chemical, and biological factors. However, the three estrogens that were most commonly found in the environmental samples were estradiol and estrone (natural estrogens), and synthetic $\mathrm{EE} 2$, which is used in oral contraceptives.

The numerical experiments were run for 15 days in order to account for the effect of spring-neap tidal variation on hydrodynamics and on dispersion of substances throughout the estuary. We chose the long-term average flow for the river inflow and climatological values for salinity and temperature, since these values represented the most typical environmental scenario.

\section{RESULTS AND DISCUSSION}

When it comes to the long-term flow regime in the SES, the numerical results found for the circulation agreed with typical estuarine circulation. During neap tides, flow in the main channel oscillated between -0.20 and +0.25 $\mathrm{ms}^{-1}$ (+ seaward).

The bathymetry of the SES (Figure 1) defines the Santos Canal as the most important feature in the estuarine dynamic because it includes the largest amount of the estuarine system in terms of volume. In this canal, most of the estuarine outflows and vertical salinity stratification are more noticeable. The horizontal distribution of salinity, which is integrated throughout a tidal cycle, determines the positioning of the estuarine front. Indeed, the front in this system is located where the salinity gradient is highest. This information is helpful for defining the estuarine mixing zone and its boundaries when the river and coastal domains are concerned.

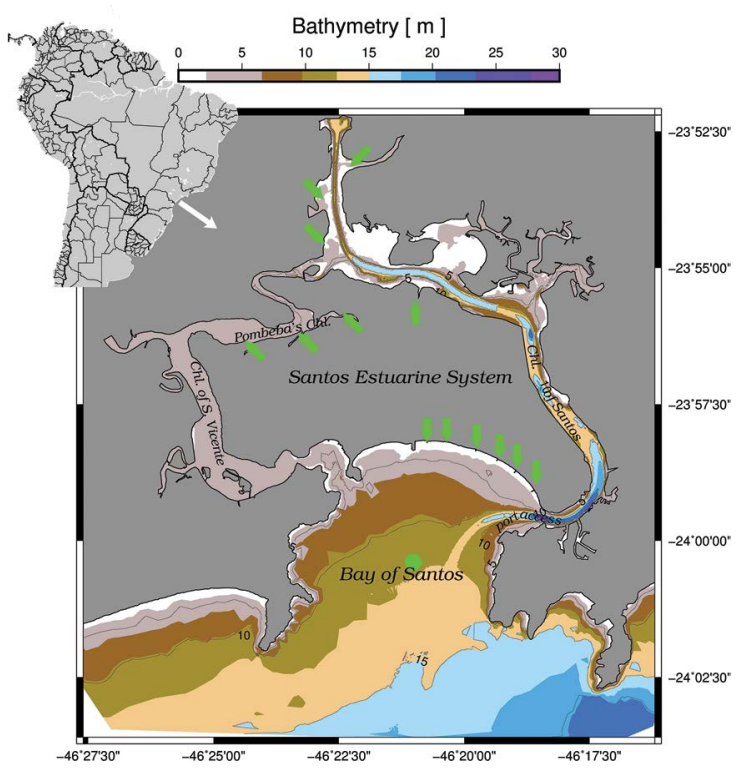

Figure 1. Santos Estuarine System (SES) bathymetry and domains. The arrows represent the discharge points into the estuary and the hexagon represents the marine outfall.

The salinity front positioning is shown in Figure 2 and reaches as far as $10 \mathrm{~km}$ from the main entrance. Another estuarine front is at the mouth of the secondary and shallower channel (the São Vicente Channel), a factor which is critical for defining water quality conditions. 


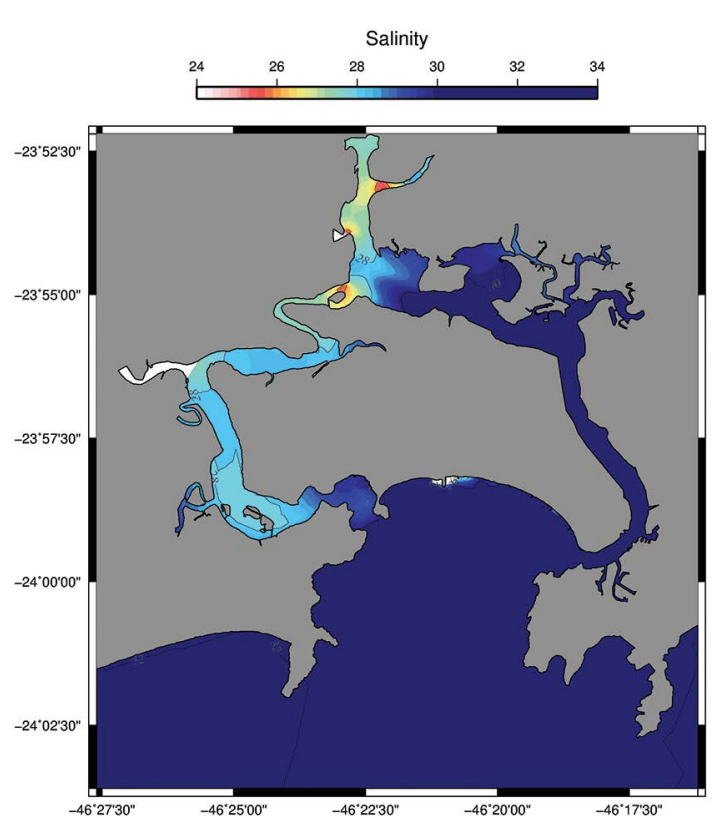

Figure 2. Horizontal distribution of salinity in the surface of the Santos Estuarine System and its bay.

\section{Residence TIME}

The results of the tidal circulation and freshwater discharge dynamics models allowed for the estimation of the residence time, which may indicate the dispersion of substances and pollutants in the SES. The results of this estimation revealed unique patterns in particular regions of the estuary, in both horizontal fields and vertical structures.

The residual flow estimate emerged after integrating tidal circulation for $355 \mathrm{~h}$, the nearest integer to the fortnightly tidal cycle. It was downstream in the western channel, where shallowness and narrowness disrupt most of the stratification. The residual flow was also downstream at the surface in the principal estuarine channel while it was upstream when depth-integrated velocities were considered.

The estimation of the residence time is:

(1)

$$
\tau=L / u_{\text {res }}
$$

where $\mathrm{L}=12000 \mathrm{~m}$ is a proxy linear distance for the SES. It was adjusted to represent the typical distance between sectors in the main channel and the bay. u_res is the residual flow. The sectors of interest are (A) the Piaçaguera Channel, located in the upper estuary; (B) the middle sector, and $(\mathrm{C})$ the port access sector. The results of the residual flow estimate are in Figure 3. For the sake of comparison, $\mathrm{L}$ was the same as in the western estuarine channel and the bay. Although stratification is important (particuarly in the main channel), residual flows were modeled based on the depth-integrated velocities.

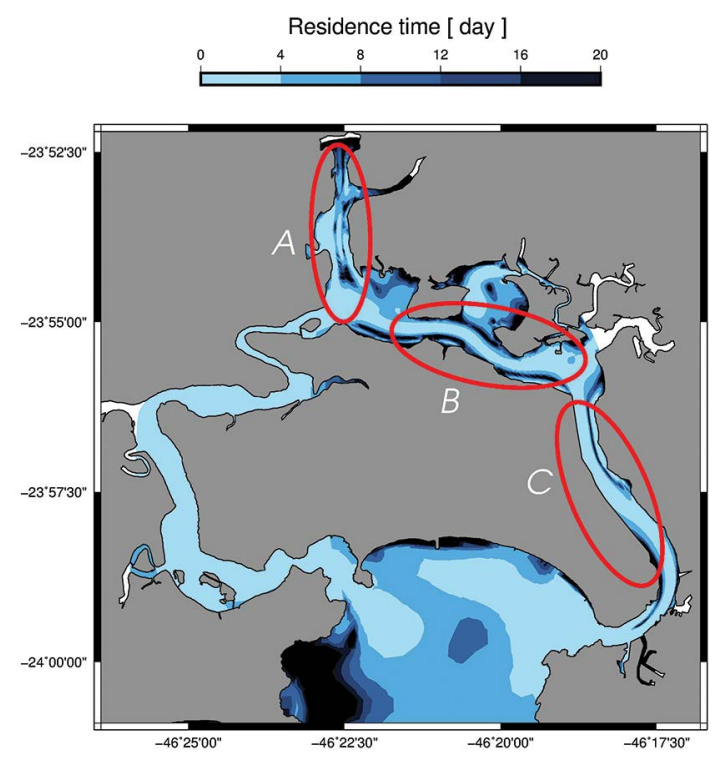

Figure 3. Estimation of residence time in the SES. Sectors A, B, and $\mathrm{C}$ correspond to the upper, mid- and lower estuary, where mean values were 8.0, 7.4, and 4.8 days, respectively. The mean values for the Pompeba Channel and the São Vicente Channel were 1.0 day.

\section{Estrogen Dispersion}

The estrogen formulation follows a mass balance approach for the advection-diffusion formulation:

(2)

$\frac{\partial C}{\partial t}+v_{x} \frac{\partial C}{\partial x}-D_{x} \frac{\partial^{2} C}{\partial x z}+v_{y} \frac{\partial C}{\partial y}-D_{y}+v_{z} \frac{\partial C}{\partial z}-D_{z} \frac{\partial^{2} C}{\partial z^{2}}=S+f_{r}(C, t)$

where: $\mathrm{S}$ and $\mathrm{f}$ are advection-diffusion-reaction functions, $\mathrm{S}$ is source inflows that were absent in the hydrodynamic model and which represent the concentration of the modeled substance present in discharges, small rivers, sewage and waste load outfalls, represents the reaction term of the estrogens and considers evaporation and dilution processes, volatilization of the substance itself, and chemical reactions. This term has been omitted, since it represents a refinement of results at a smaller order of magnitude. The other terms in Equation (2) are concentration of the substance (C), the diffusion coefficient (D) and flow velocity (v). All variables were measured in terms of the three spatial dimensions ( $x, y$, and $\mathrm{z}$ ) and time (t). 
Results for the dispersion modeling analyses can be found in Figure 4. The dispersion rates of the three estrogens within the study area reveal higher concentrations in the Pompeba Channel, the São Vicente Channel, and the Santos Bay. The concentration values were determined to be $0-0.5 \mathrm{ng} \mathrm{L}^{-1}$ in the case of estradiol and $0.06-0.25 \mathrm{ng} \mathrm{L}^{-1}$ in the case of EE2. Estrone showed the highest concentration value at $0.6-1.2 \mathrm{ng} \mathrm{L}^{-1}$.

The modeled concentration results were below the limit values for toxicity in aquatic organisms, except in the case of EE2. The estimated EE2 concentrations were between 0.06 and $0.25 \mathrm{ng} \mathrm{L}^{-1}$, which is within the toxic range of 0.1 - $100 \mathrm{ng} \mathrm{L}^{-1}$, levels which are harmful to some species of aquatic organisms (PAWLOWSKI et al., 2004; FOLMAR et al., 2000; RODGRES-GRAY et al., 2000; ROUTLEDGE et al., 1998).

These results suggest that estrogens are unlikely to cause adverse effects on the biota in the SES environment, since the concentrations of estrogens in surface waters were generally found to be below toxic thresholds. However, one cannot give any assurance that the nearby discharge sources are free of acute or chronic toxicity: concentrations were above $0.1 \mathrm{ng} \mathrm{L}^{-1}$ in some portions of the SES, such as the São Vicente Channel. The sedimentwater partition coefficient (log Koc) for estrogens increases as salinity increases (LAI et al., 2000). Salinity may be a factor in the sorption of these compounds by sediments and organic matter. These factors may change estrogen dispersal levels in aquatic environments. Salinity is higher in the Santos Channel because the channel is the deeper domain, so it is there the lowest concentrations of estrogens are found. Consequently, sediments in the region may adsorb estrogens more efficiently, though this process has not been modeled.

The relatively higher concentration of hormones in Pompeba Channel can be explained by the illegal discharge of sewage from both shantytowns and residential areas, as well as by the dispersion conditions imposed by the hydrodynamic regime and channel morphology. The small channels drain wastewater from the surrounding neighborhoods and release it into the estuary. The amount of fecal coliforms found in samples collected in this region of the estuary exceeds the legally permitted standards, a finding which shows that this region is strongly influenced by sewage discharges. The values have progressively increased in recent years, and domestic sewage remains a primary pollutant in this region (SAMPAIO et al., 2008).

The residence time ranges from 1 to 8 days and does not pose any significant influence on estrogen concentrations in different locations of the SES. The hydrodynamic regime and the differences in the volume of the sectors are indeed the most important aspects to consider when determining which regions have the highest concentrations of estrogens (nearby outflow source locations, for example).

Contraceptives and hormonal treatment pharmaceuticals are linked to socioeconomic issues, since they are widely consumed by the local population. The synthetic estrogen EE2 passes through the sewage disposal system and is dispersed throughout the environment.

In addition to its significant economic importance, Santos is the largest city in the region in terms of
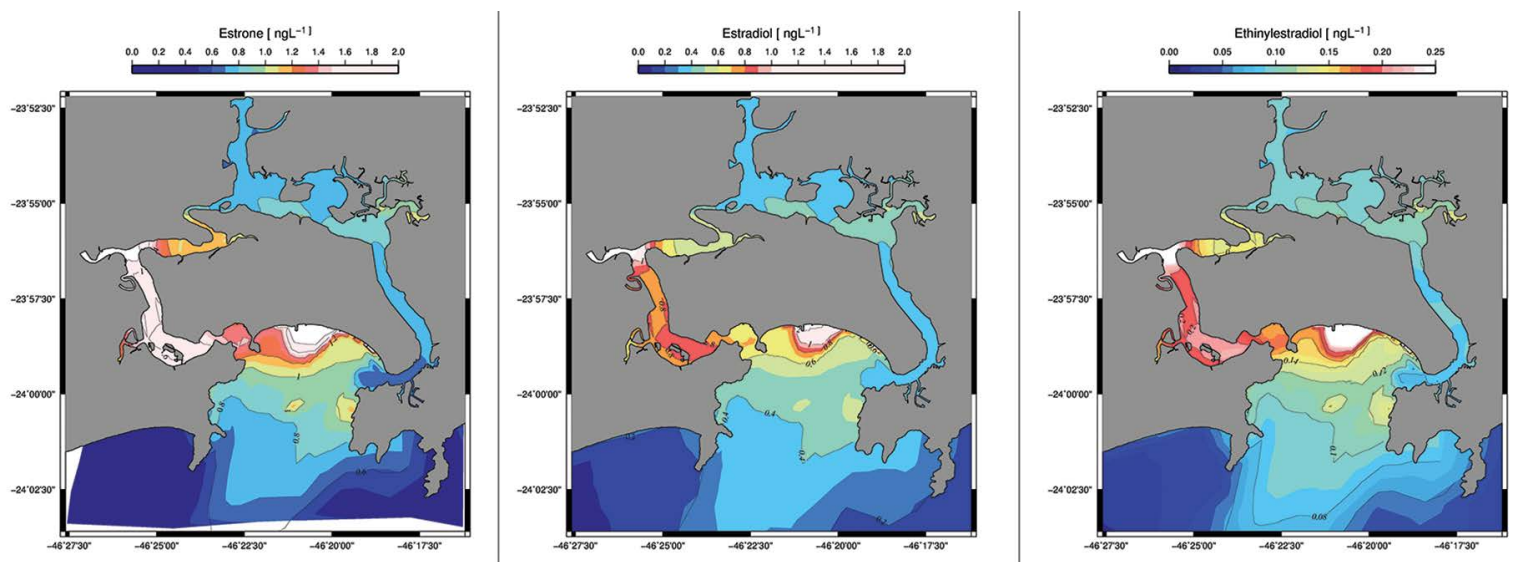

Figure 4. A: Horizontal distribution of natural and synthetic estrogens in the surface waters of the Santos Estuarine System and its bay. Results after 15 days of simulation with the average long-term flow rate. a) Estradiol; b) Estrone; c) EE2. B: Horizontal distribution of natural and synthetic estrogens in the surface waters of the Santos Estuarine System and its bay. Results after 15 days of simulation with the average long-term flow rate. a) Estradiol; b) Estrone; c) EE2. C: Horizontal distribution of natural and synthetic estrogens in the surface waters of the Santos Estuarine System and its bay. Results after 15 days of simulation with the average long-term flow rate. a) Estradiol; b) Estrone; c) EE2. 
urbanized land area, and it has the highest population density per square kilometer with a total of more than 400,000 inhabitants. The city currently has more women than men; the current ratio being approximately 80 males to 100 females (SEADE, 2012; IBGE, 2010). Areas with potential sources of estrogens may be contributing to health risks for the population that uses the waters of the estuary for leisure and recreation. These activities allow for contact with and ingestion of contaminated compounds. Estrogens may also contribute to toxicity levels in aquatic biota through their synergism with other chemicals present in domestic effluents.

Further investigations in this area will ideally consider sampling and monitoring in the regions studied in this paper.

\section{RECOMMENDATIONS FOR FUTURE RESEARCH}

The routes of exposure to estrogens and the presence of these hormones in the region surrounding the Santos Estuary System should consider the influence of $\mathrm{pH}$, temperature, and thermodynamic parameters on the dispersion and sorption kinetics of estrogens. Other studies could quantify environmental compartments in the region or perform ecological risk assessments using ecotoxicological information and other lines of evidence. Still others can include research results on the consumption of birth control pills by the local female population. For the sake of the greater refinement of results, the chemical reactions of estrogens might consider the effect of salinity and sediment sorption at different concentrations in subdomains of the SES. Salinity distribution in sediments is a key issue within the comprehensive analysis of the kinematics of endocrine disruptors in highly impacted subtropical estuaries.

\section{REFERENCES}

BELFROID, A. C.; VAN DER HIORST, A.; VETHAAK, A. D.; SCHÄFER, A. J.; RIJIS, G. B. J.; WEGENER, J. CONFINO, W. P. Analysis and occurrence of estrogenic hormones and their glucuronides in surface water and waste water in The Netherlands. Sci. Total. Environ., v. 225, n. 1/2, p. 101-108, 1999.

BILA, D. M.; DEZOTTI, M. Desreguladores endócrinos no meio ambiente: efeitos e conseqüências. Quím. Nova, v. 30, n. 3, p. 651-666, 2007.

FOLMAR, L. C.; HEMMER, M.; HEMMER, R.; BOWMAN, C.; KROLL, K.; DENSLOW, N. D. Comparative estrogenicity of estradiol, ethynyl estradiol and diethylstilbestrol in an in vivo, male sheepshead minnow (Cyprinodon variegatus), vitellogenin bioassay. Aquat. Toxicol., v. 49, n. 1/2, 77-88, 2000.
FRF. Fundação Ricardo Franco. Estudo de Impacto Ambiental (EIA) e Relatório de Impacto Ambiental (RIMA): Projeto de Aprofundamento do Canal de Navegação do Porto de Santos. Santos, 2008.

GHISELLI, G.; JARDIM, W. F. Interferentes endócrinos no ambiente. Quím. Nova, v. 30, n. 3, p. 695-706, 2007.

HARARI, J.; FRANÇA, C. A. S.; CAMARGO, R. Climatology and Hydrography of Santos Estuary. In: NEVES, R.; BARETTA, J.; MATEUS, M. (Eds.). Perspectives on integrated coastal zone management in South America. Lisboa: IST Press, 2008. p.147-160.

BRASIL. IBGE. Instituto Brasileiro de Geografia e Estatística 2012. Censo demográfico, 2010. Available at: < http://www. ibge.gov.br/home/estatistica/populacao/censo2010/>. Accessed on 20 Dec. 2015.

ISOBE, T.; SERIZAWA, S.; HORIGUCHI, T.; SHIBATA, Y.; MANAGAKI, S.; TAKADA, H.; MORITA, M.; SHIRASHI, H. Horizontal distribuition of steroid estrogens in surface sediments in Tokio Bay. Environ. Pollut., v. 144, n. 2, p. 632638, 2006.

JOBLING, S.; NOLAN, M.; TYLER, C. R.; BRIGHTY, G.; SUMPTER, J. P. Widespread sexual disruption in wild fish. Environ. Sci. Technol., v. 32, p. 2498-2506, 1998.

LAI, K. M.; JOHNSON, K. L.; SCRIMSHAW, M. D.; LESTER, J. N. Binding of waterborne Steroid estrogens to solid phases in river and estuarine Systems. Environ. Sci. Technol., v. 34, p. 3890-3894, 2000.

LAMPARELLI, C. C. Desafios para o licenciamento e monitoramento ambiental de emissários: A experiência de São Paulo. In: LAMPARELLI, C. C.; ORTIZ, J. P. Emissários submarinos: Projeto, avaliação de impacto ambiental e monitoramento. Relatório Técnico CETESB. Secretaria do Meio Ambiente do Estado de São Paulo. Escola Politécnica da Universidade de São Paulo: EPUSP, 2006. $240 \mathrm{p}$.

LAMPARELLI, M. L.; COSTA, M. P.; PRÓSPERI, V. A.; BEVILÁCQUA, J. E.; ARAÚJO, R. P. A.; EYSINK, G. G. L.; POMPÉIA, S. Sistema Estuarino de Santos e São Vicente. Relatório Técnico CETESB: São Paulo, 2001. 178 p.

MIRANDA, L. B.; OLLE, E. D.; BÉRGAMO, A. L.; SILVA, L. S.; ANDUTTA, F. P. Circulation and salt intrusion in the Piaçaguera Channel, Santos (SP). Braz. J. Oceanogr., 60, n. 1, p. 11-23, 2012.

MULROY, A. When the cure is the problem. Water Environ. Technol., v. 13, n. 2, p. 32-36, 2001.

PAWLOWSKI, S.; VAN AERLE, R.; TYLER, C. R.; BRAUNDECK, T. Effects of 17alpha-ethinylestradiol in a fathead minnow (Pimephales promelas) gonadal recrudescence assay. Ecotoxicol. Environ. Saf., v. 57, n. 3, p. 330-345, 2004 .

ROBINSON, B.; HUI, J. P.; SOO, E.; HELLOU, J. Estrogenic compounds in seawater and sediment from Halifax Harbor, Nova Scotia, Canada. Environ. Toxicol. Chem., v. 28, n.1, p. 18-25, 2009.

RODGERS-GRAY, T. P.; JOBLING, S.; MORRIS, S.; KELLY, C.; KIRBY, S.; JAMBAKHSH, A.; HARRIES, J. E.; WALDOCK, M.; SUMPTER, J. P.; TYLER, C. R. Long-term temporal changes in the estrogenic composition of treated sewage effluent and its biological effects in fish. Environ. Sci. Technol., v. 34, p. 1521-1528, 2000. 
ROUTLEDGE, E. J.; SHEAHAN, D.; DESBROW, C.; BRIGHTY, G. C; WALDOCK, M.; SUMPTER, J. P. Identification of estrogenic chemicals in STW effluent. 2. In vivo responses in trout and roach. Environ. Sci. Technol., v. 32, p. 1559-1565, 1998.

SAMPAIO, A. F. P.; MATEUS, M.; RIBEIRO, R. B. Assessing the impact of several development scenarios on the water quality in Santos Estuary. In: NEVES, R; BARETTA, J. W.; MATEUS, M. Perspectives on integrated coastal zone management in South America. Lisboa: IST Press, 2008. p. 435-444.

SEADE. Fundação Sistema Estadual de Análise de Dados, 2012. Available at: <http://www.seade.gov.br/>. Accessed on: 17 Nov 2015.

STUMPF, M.; TERNES, T. A.; WILKEN, R. D.; RODRIGUES, S. V.; BAUMANN, W. Polar drug residues in sewage and natural waters in the state of Rio de Janeiro, Brazil. Sci. Total Environ., v. 225, n. $1 / 2$, p. 135-141, 1999.
TERNES, T. A.; STUMPF, M.; MUELLER, J.; HABERER, K.; WILKEN, R. D.; SERVOS, M. Behavior and occurrence of estrogens in municipal sewage treatment plants--I. Investigations in Germany, Canada and Brazil. Sci. Total. Environ., v. 225, n. 1/2, p. 81-90, 1999.

TERNES, T. A. Analytical methods for the determination of pharmaceuticals in aqueous environmental samples. Trends Analyt. Chem., v. 20, n. 8, p. 419-434, 2001.

WRITER, J. H.; RYAN, J. N.; KEEFE, S. H.; BARBER, L. B. Fate of 4-nonylphenol and 17ß-estradiol in the Redwood River of Minnesota. Environ. Sci. Technol.; v. 46, n. 2, p. 860868,2012

YING, G. G.; KOOKANA, R. S.; RU, Y.; RU, J. R. Occurrence and fate of hormone steroids in the environment. Environ. Int., v. 28, n. 6 , p. $545-551,2002$. 